Policy Brief

\title{
Stillehavsøsters
}

- en ny nordisk fødevare-

ressource og et grundlag

for turisme

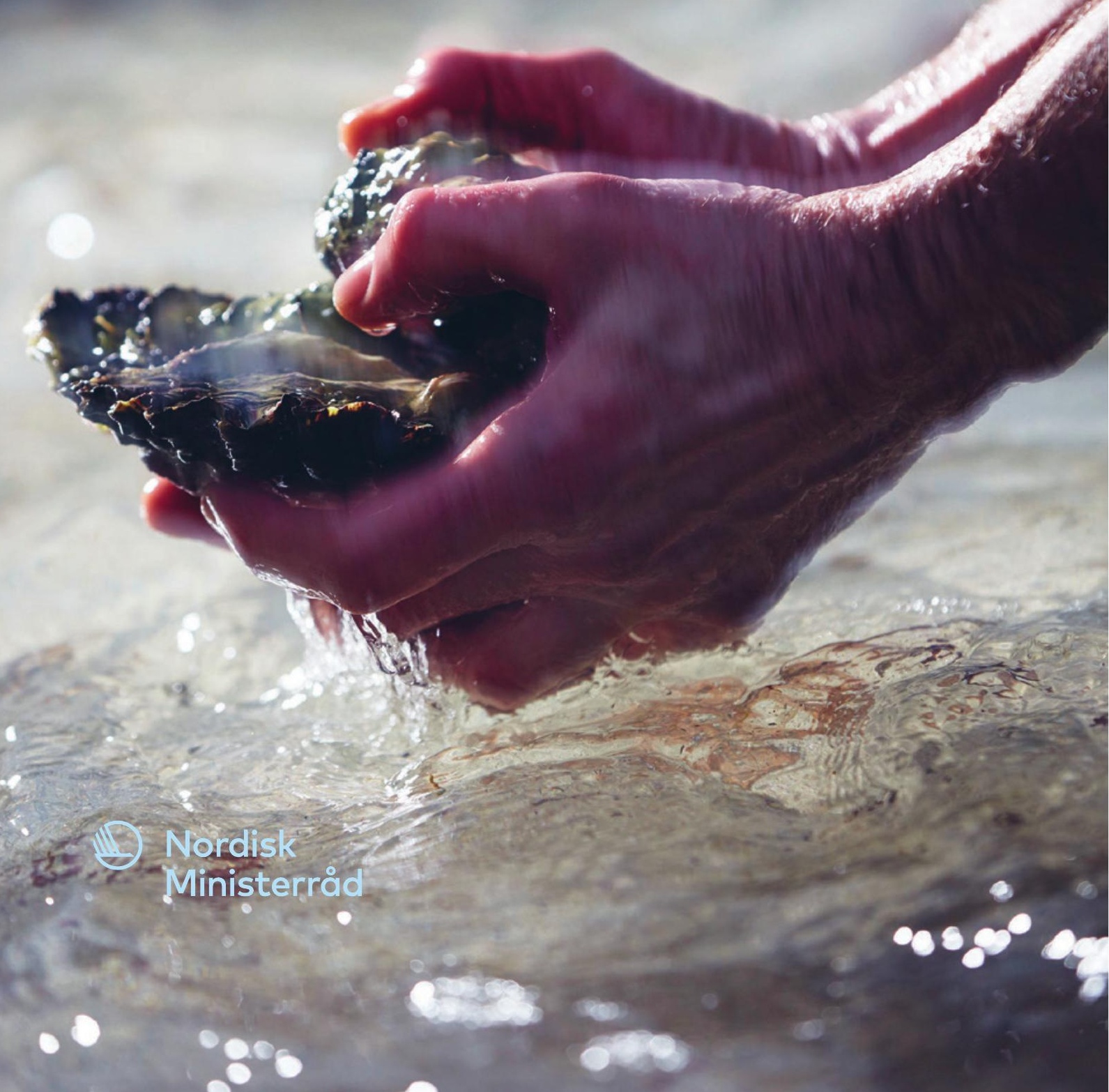




\section{Stillehavsøsters - en ny nordisk fødevareressource og et grundlag for turisme}

Stein Mortensen, Per Dolmer, Åsa Strand, Lars-J. Naustvoll og Ane Timenes Laugen

Nord 2019:016

ISBN 978-92-893-6136-1 (PRINT)

ISBN 978-92-893-6137-8 (PDF)

ISBN 978-92-893-6138-5 (EPUB)

http://dx.doi.org/10.6027/Nord2019-016

(c) Nordisk Ministerråd 2019

Layout: Mette Agger Tang

Omslagsfoto: Øystein Klakegg

Tryk: Rosendahls

Printed in Denmark

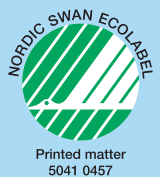

\section{Det nordiske samarbejde}

Det nordiske samarbejde er en af verdens mest omfattende regionale samarbejdsformer. Samarbejdet omfatter Danmark, Finland, Island, Norge og Sverige samt Færøerne, Grønland og Åland.

Det nordiske samarbejde er både politisk, økonomisk og kulturelt forankret, og er en vigtig medspiller i det europæiske og internationale samarbejde. Det nordiske fællesskab arbejder for et stærkt Norden i et stærkt Europa.

Det nordiske samarbejde ønsker at styrke nordiske og regionale interesser og værdier i en global omverden. Fælles værdier landene imellem er med til at styrke Nordens position som en af verdens mest innovative og konkurrencedygtige regioner.

\section{Nordisk Ministerråd \\ Nordens Hus \\ Ved Stranden 18 \\ 1061 København $\mathrm{K}$ \\ www.norden.org}

Download og bestil nordiske publikationer: www.norden.org/nordpub 


\section{Policy Brief}

\section{Stillehavsøsters \\ - en ny nordisk fødevare- ressource og et grundlag for turisme}

\section{Indhold}

05 Stillehavsøsters - trussel eller ny ressoruce?

07 Fordelingen af østers og deres miljømæssige følger

08 Begrænsning af invasive arter

09 Kommerciel udnyttelse af stillehavsøsters i Norden

11 Regionale østers - eller betydningen af merroir

12 Udfordringer

14 Konklusioner og anbefalinger

15 Udvalgt litteratur 
.

-

$e^{2}$

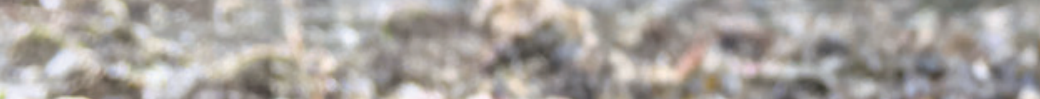
That

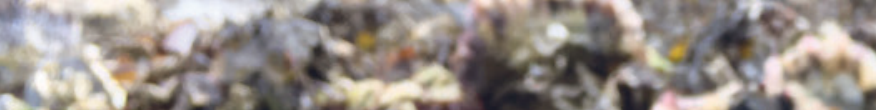

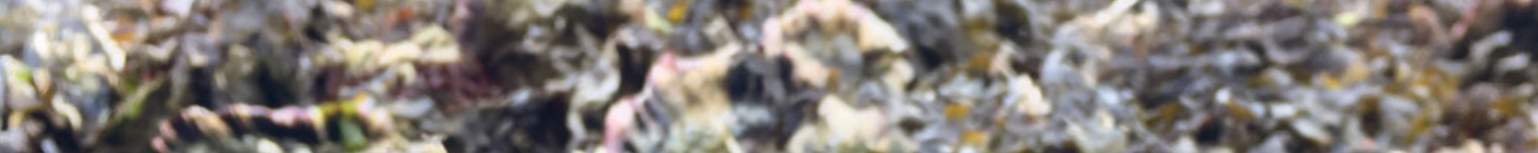

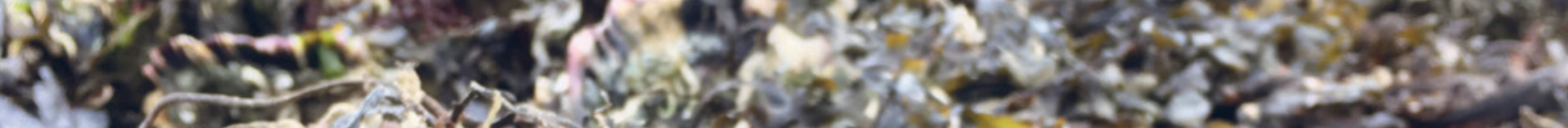

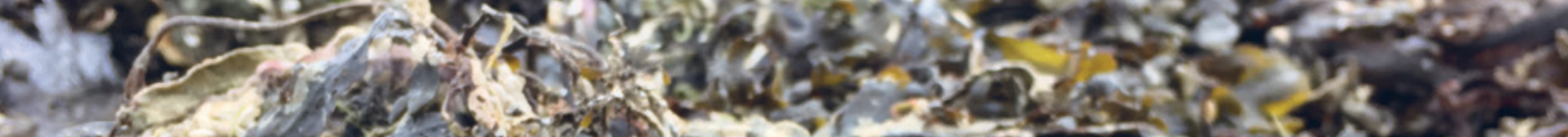
J.

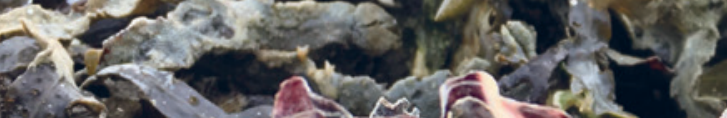

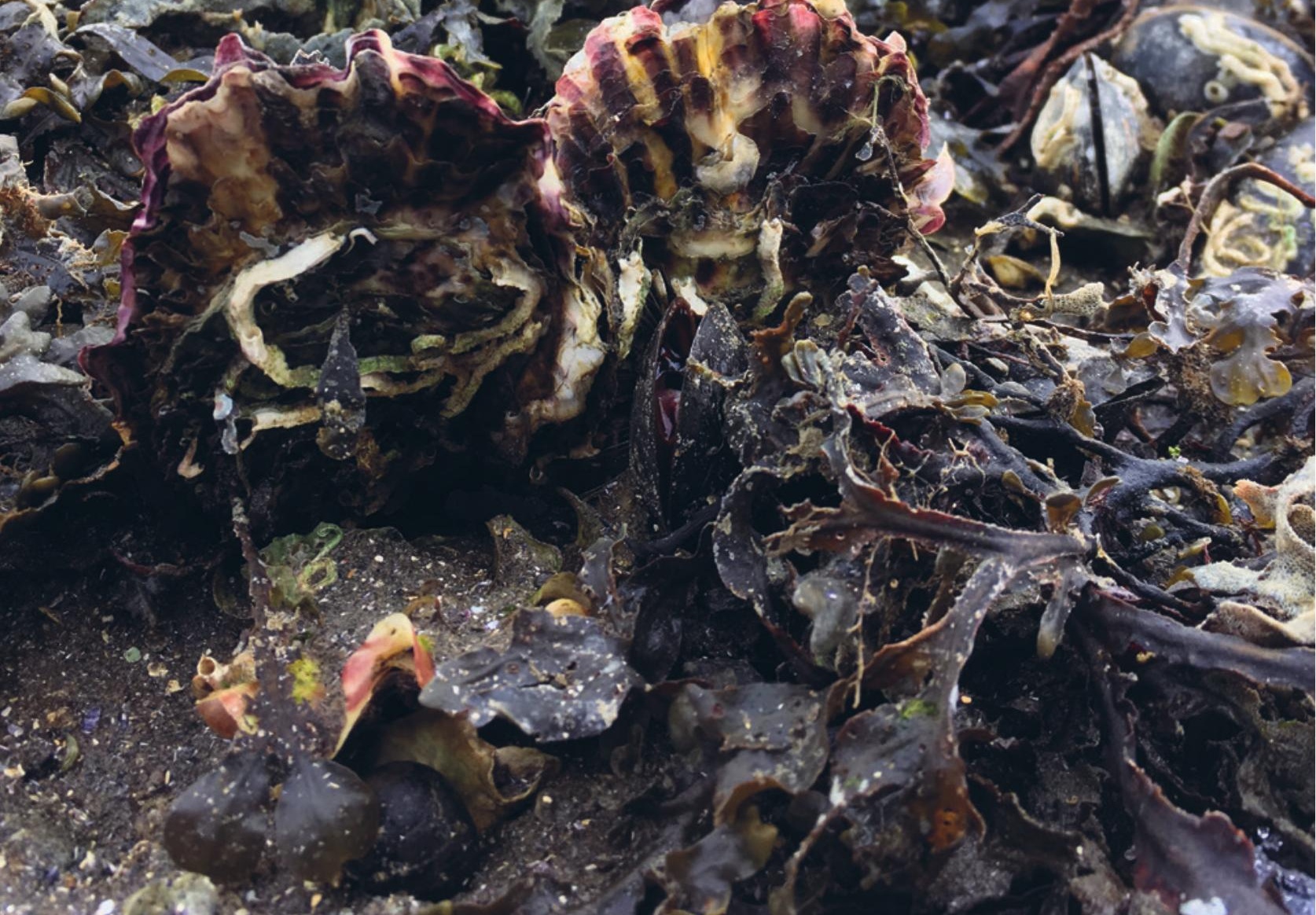

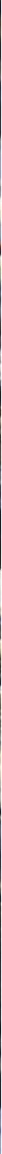




\section{Stillehavsøsters}

- trussel eller ny ressoruce?

Siden 2007 har stillehavsøsters etableret stabile og kompakte bestande i skandinaviske kystfarvande. Arten anses som fremmed og invasiv, og kompakte bestande kan forårsage ændringer i bundforholdene. Den er dog også en af verdenens vigtigste akvakultur-arter, og der er en voksende interesse $i$, at bruge de skandinaviske bestande som en ny marin ressource.

For at frigøre det kommercielle potentiale er der et akut behov for en bedre forståelse af, hvordan stillehavsøsters påvirker økosystemet samt en afklaring af forskellige juridiske forhold såvel som etablering af en forvaltningspraksis for høst og markedsføring af disse østers. Produktionsmetoder og fødevarekontrol bør også være på plads, for at garantere at kun sikre og sunde østers kommer på markedet.

Dette policy brief opsummerer den nuværende status for stillehavsøsters i Skandinavien og fremlægger anbefalinger for fremtidigt arbejde med og administration af stillehavsøsters i de nordiske lande. 
I Vadehavet i det sydlige Danmark er der opbygget banker med stillehavsøsters.

Foto: Per Dolmer $\rightarrow$

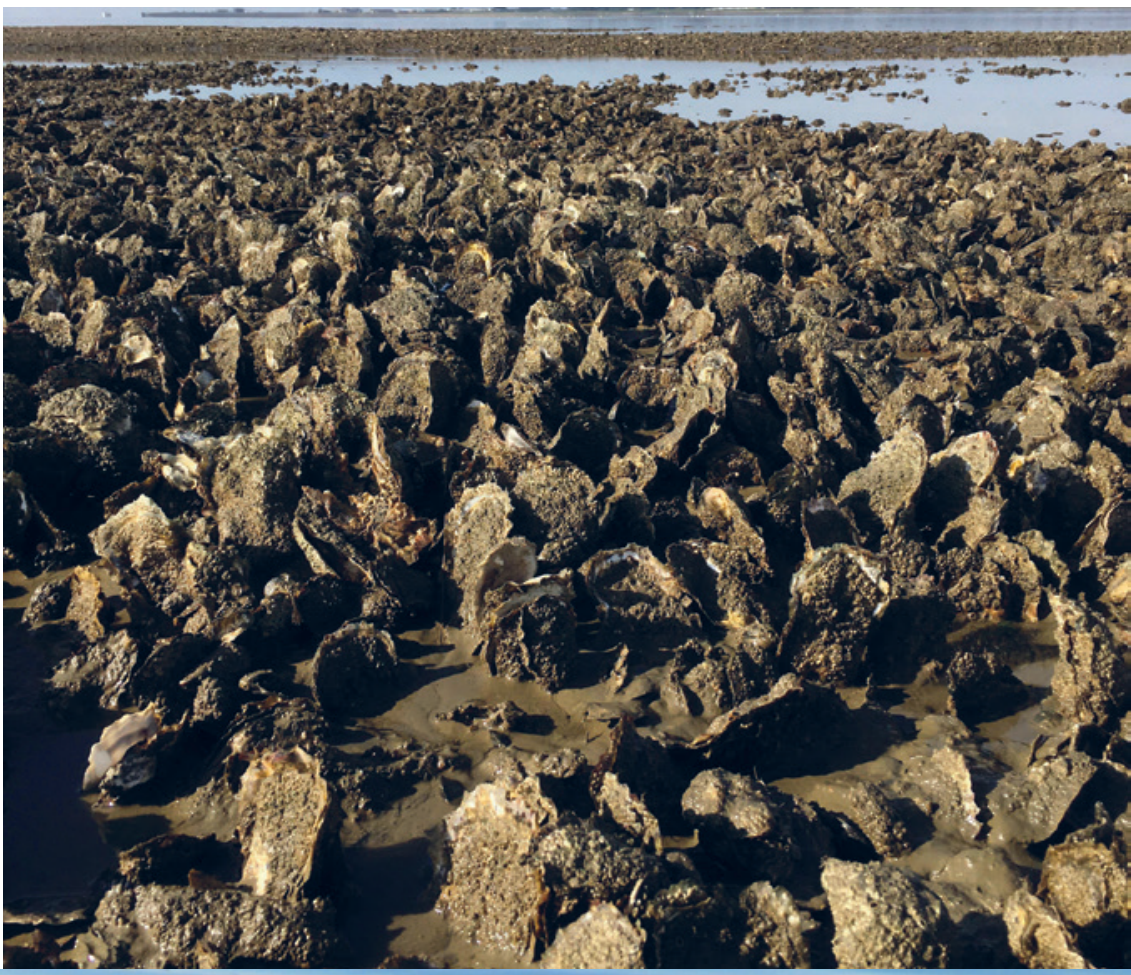

Edderfuglen er en af de fugle, som lever af blåmuslinger. Kan stillehavsøsters være en trussel mod blåmuslinger og dermed mod edderfuglen?

Foto: Arne Duinker $\omega=5$,
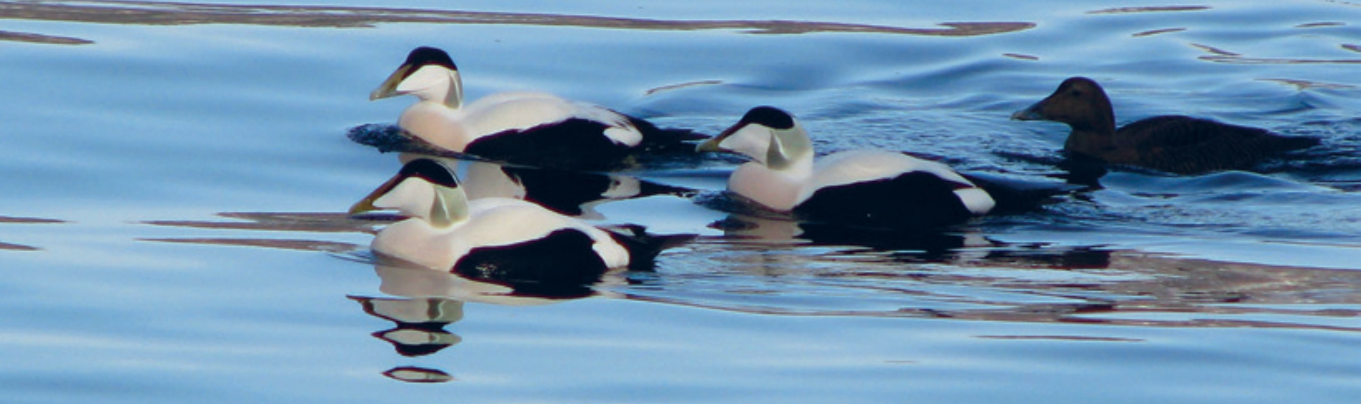

- -1
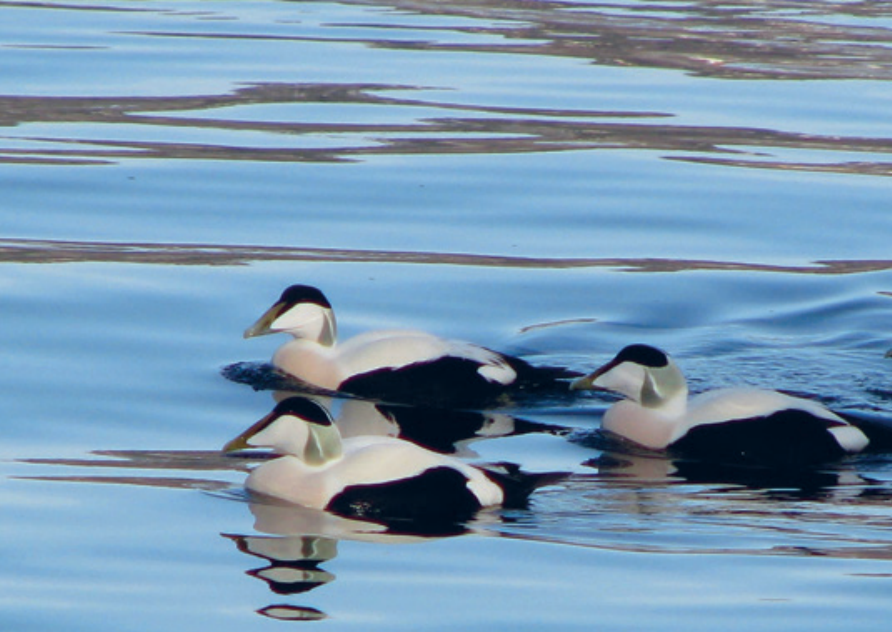


\section{Fordelingen af østers og deres miljømæssige følger}

Stillehavsøsters, Crassostrea gigas, blev introduceret fra Sydøstasien til Europa. Introduktioner af arten til akvakultur startede i 1964 og forsatte ind i 1970'erne. Østers spredte sig fra akvakultur-områder og etablerede selvforsynende bestande i lavvandede kystområder. Arten etableredes i danske farvande i midten af 1990'erne og har i dag også koloniseret den svenske vestkyst og den norske kyst op til nord for Bergen. Vores studier viser, at de nordiske bestandes oprindelse kan være østers fra sydligere farvand, hvis efterkommere langsomt har spredt sig nordpå. Mens det er svært at forudsige artens endelige fordeling og omfang, har den for nyligt - overraskende nok - også spredt sig sydpå til Øresund. For tiden samarbejder danske, svenske og norske marinbiologiske forskere om at monitorere og forudsige bestandens udbredelse og dynamik i forskellige skandinaviske kystområder.

Stillehavsøsters kan - når der findes passende levesteder - etablere meget kompakte bestande og østersrev, der ændrer på økosystemet. Både forskere og forvaltere har vurderet, at disse bestande vil forårsage en række negative virkninger på økosystemet, såsom ændringer i miljøer domineret af blåmuslinger, inklusive ændringer for dyr, der lever af muslingerne (såsom edderfugle). I nogle områder overlapper udbredelsen af stillehavsøsters med den oprindeligt hjemmehørende europæiske østers. Dette har været årsag til bekymring over, hvorvidt bestande af europæisk østers vil blive overgroet af stillehavsøsters.

I Tyskland og Holland, hvor ændringer på økosystemer forårsaget af stillehavsøsters er blevet grundigt studeret, har der været et tydeligt skift i opfattelsen af stillehavsøsters. Nu fokuseres der på de positive virkninger, såsom formationen af såkaldte biogene rev. Disse rev tilvejebringer plads og beskyttelse for en stor mængde organismer, og bidrager dermed til en højere biodiversitet. I Skandinavien tyder det også på, at virkningerne af stillehavsøsters er mindre negative end forudset, men manglen på grundlæggende data fra Skandinavien betyder, at sådanne analyser er usikre. 


\section{Kommerciel udnyttelse af stillehavsøsters i Norden}

Stillehavsøsters er en af verdens vigtigste akvakultur-arter med en årlig produktion på adskillige millioner tons på et stort globalt marked. I Europa findes de største produktioner i Frankrig, Spanien, Storbritannien og Irland. Siden 2008 har de primære europæiske produktionsområder for stillehavsøsters været påvirket af sygdomme, der begrænser produktion og indtægt.

Tilstedeværelsen af stillehavsøsters i Skandinavien åbner muligheder for etablering af nye kommercielle aktiviteter. Høst i mindre omfang, hvor østers indsamles i hånden, sorteres, renses og sælges på lokale markeder, har allerede været igangsat. I Danmark leveres små mængder stillehavsøsters også som bifangst fra skrabefiskeri efter blåmuslinger i Limfjorden. I 2013 etablerede hollandske fiskere et bæredygtigt (MSC-certificeret) østersfiskeri, der kunne bruges som model for, hvordan der kan etableres høst af vilde stillehavsøsters $i$ Skandinavien.

Der er også blevet udviklet nye turismekoncepter såsom østerssafari. Lokale virksomheder arrangerer ture til områ-

Mange stillehavsøsters sidder godt fast på klipper eller stenblokke. Det er svært at udnytte dem. Det er vigtigt at få undersøgt, hvor stor en del af bestandene, som kan høstes.

Foto: Nicolay Moe $\rightarrow$

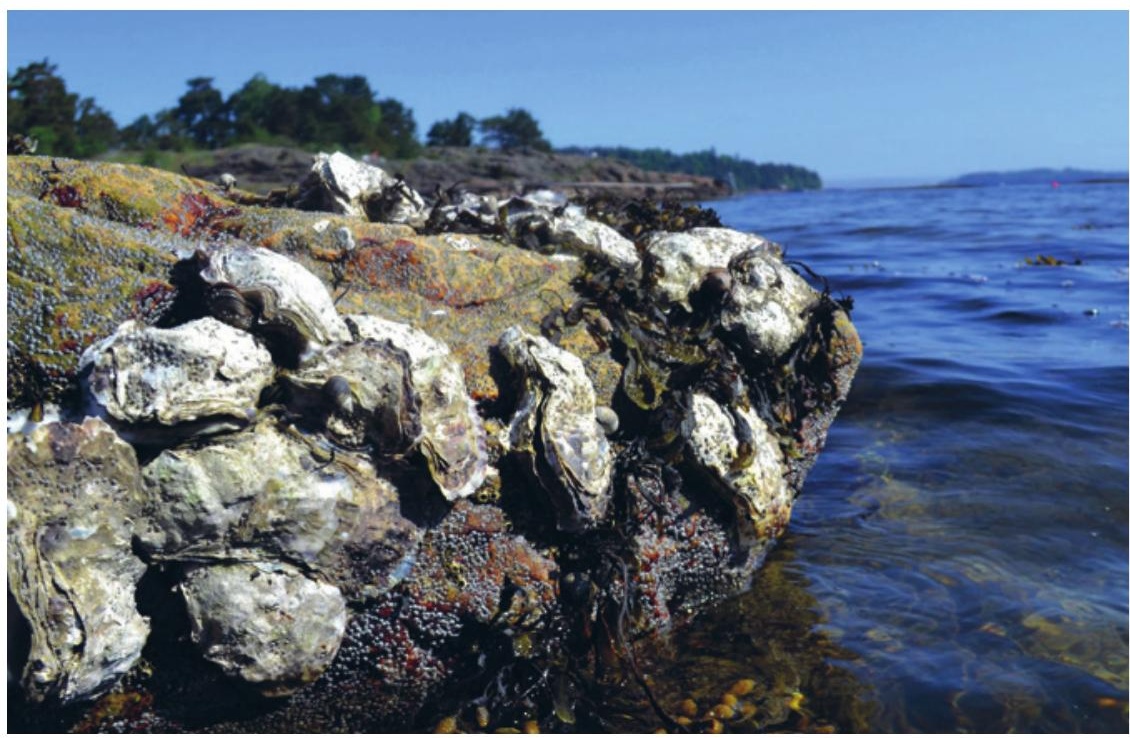




\section{Regionale østers \\ - eller betydningen af merroir}

"Vil du have en skagerakøster, en vadehavsøster eller en orustøster" vil du måske blive spurgt i en restaurant om et par år - hvis østersindustriens potentiale udløses. I lande, hvor østers er polulære, såsom Frankrig og USA, er østers geografiske oprindelse et vigtigt aspekt af markedsføringen. Østers har forskellige kvaliteter og smagsprofiler afhængigt af opdrætssted. Variationerne kan skyldes forskelle i fødeforhold og vandets indhold af salte og mineraler fra havbunden. For marine fødevareprodukter, inklusive stillehavsøsters, benyttes termen merroir for produktets unikke oprindelse. Stillehavsøsters har en smagsprofil, som er anderledes fra europæisk østers. Ved at markedsføre begge arter af nordiske østers fra forskellige nordiske regioner kan man forhøje østerssektorens økonomiske værdiskabelse, og merroir-konceptet bør derfor udvikles yderligere.
På Torvehallene i

København sælges

allerede forskellige

typer østers fra forskel-

lige regioner. Snart

udvides udvalget måske med stillehavsøsters fra flere steder i Norden.

Foto: Stein Mortensen $\rightarrow$

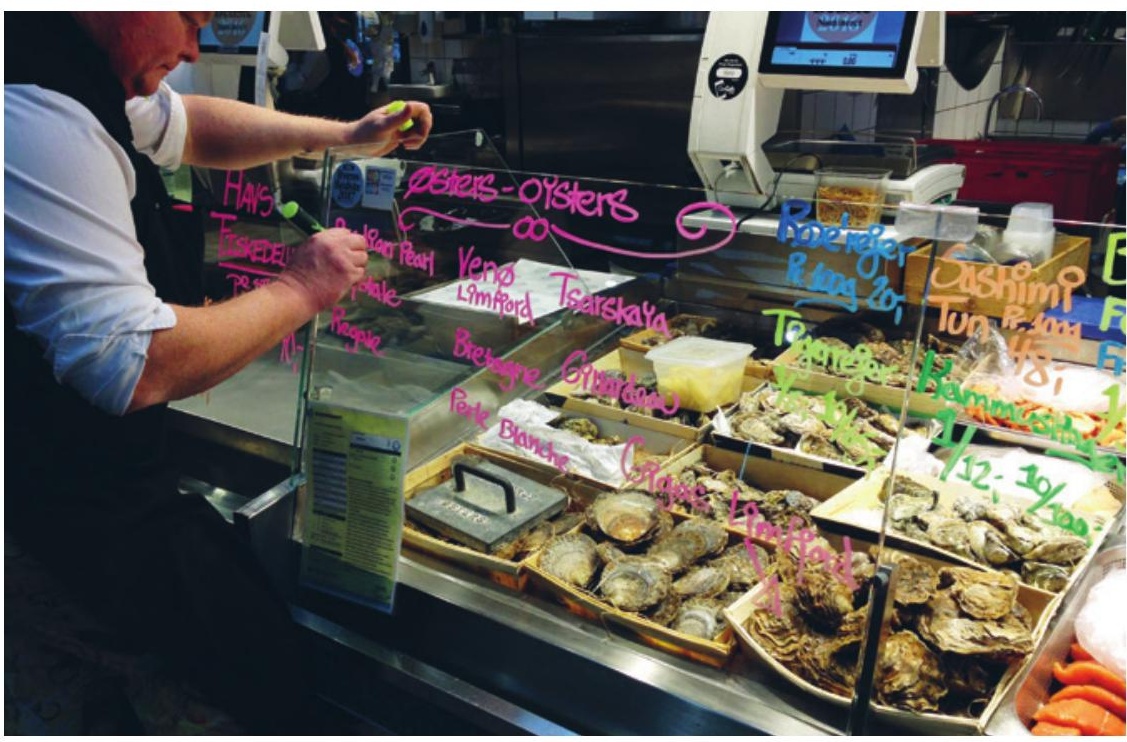




\section{Udfordringer}

Den voksende interesse for at bruge nordiske stillehavsøsters som en ny ressource kræver, at man afklarer forskellige problemstillinger i forhold til at kunne realisere potentialet.

For det første er en afklaring af juridiske forhold vedrørende høst af stillehavsøsters på lavt vand absolut nødvendigt for nye virksomheder, der stræber efter at udnytte denne ressource. I Danmark er østers statens ejendom, og enhver privat person kan høste østers til eget forbrug. For kommerciel høst er det påkrævet at have en tilladelse fra Fiskeristyrelsen. Derudover skal Fødevarestyrelsen åbne nye produktionsområder for høst. Disse baseres på en vidtgående prøvetagning og kontrol af fødevarekvaliteten. I Sverige er det ejeren af grunden, der ligger ud til kysten, som ejer alle østers ud til 200 meter fra kysten. Dermed kan grundejeren give tilladelse til kommerciel høst.

I Norge er retten til at udnytte ressourcerne på lavt vand ikke reguleret af lovgivning, men ifølge afgørelser truffet af den norske højesteret, er det grundejeren, der ejer ressourcerne ud til en dybde på to meter ved lavvande. Offentligheden må indsamle østers til eget forbrug, men dette kan stride imod grund- ejerens eneret, hvis denne har valgt at udnytte ressourcen.

Den anden udfordring er en implementering af systemer, der kan understøtte skaldyrsindustriens akilleshæl: fødevaresikkerhed. Salg af smittebærende østers, der kan forårsage sygdom for indtageren, vil give østers et dårligt ry, skade forbrugerens tillid og formindske rentabiliteten af en produktion. For at kunne opbygge et stort, stabilt, lokalt marked for stillehavsøsters er det vigtigt at forbrugerne stoler på produktet og har god grund til det. Fødevaresikkerhed er også afgørende for fritidshøst - privat såvel som organiserede østersture.

Fødevaremyndighederne er ansvarlige for at sikre forbrugernes sikkerhed, og alle de nordiske lande ligger under den samme EU-forordning 178/2002 (generel fødevarelovgivning) og forordninger for fødevarehygiejne (eks. 852/2004 og 853/2004). Østers til indtag for mennesker skal kontrolleres og godkendes i overensstemmelse med disse forordninger. Grundet utilstrækkelig viden om effekten af norovirus, algetoksiner og tungmetaller på stillehavsøsters kan nordiske fødevaremyndigheder ikke give sikker rådgivning til fritidshøstere. Vi understreger vigtigheden af at etablere 
og udvide forskning i fødevaresikkerhed i de igangværende programmer for monitorering af skaldyr for at sikre, at myndighederne kan give evidensbaseret rådgivning. Monitorering af giftige alger og kontrol af virusser, bakterier, algetoksiner og andre skadelige kontaminanter i østers vil også blive værdifuldt for fritidshøst, forudsat at resultaterne gøres offentlige. I det igangværende arbejde med at udvikle kommercielle aktiviteter omhandlende stillehavsøsters bør vi forøge både viden og monitorering og udvikle tilstrækkelige redskaber til at sikre forbrugernes sikkerhed.

Den tredje udfordring for en spirende industri indenfor stillehavsøsters er adgang til stabile naturressourcer. I praksis betyder dette en adgang til ro- buste bestande af høstbare østers og videnskabelig rådgivning om effekten af miljømæssige svingninger i bestandenes størrelser. Studier fra den nordlige del af det tyske vadehav og fra skandinaviske kystområder har vist, at østers i lavvandede områder har en lav overlevelsesrate gennem vintre med store mængder havis. Varme somre kan også resultere i sommerdødeligheder grundet infektion med den ostreide herpesvirus (OsHV-1). Til trods for disse "flaskehalse" er de nordiske bestande af stillehavsøsters fortsat med at vokse, og vi forudser yderligere udvidelse og vækst af bestande i de kommende år. Fortsat kortlægning af nye forekomster såvel som udbredelse af de begrænsede igangværende monitoreringer bør derfor være en prioriteret aktivitet for nordiske myndigheder.
Nordiske forskere samarbejder om at overvåge og kortlægge bestandene af stillehavsøsters.

Foto: Åsa Strand $\rightarrow$

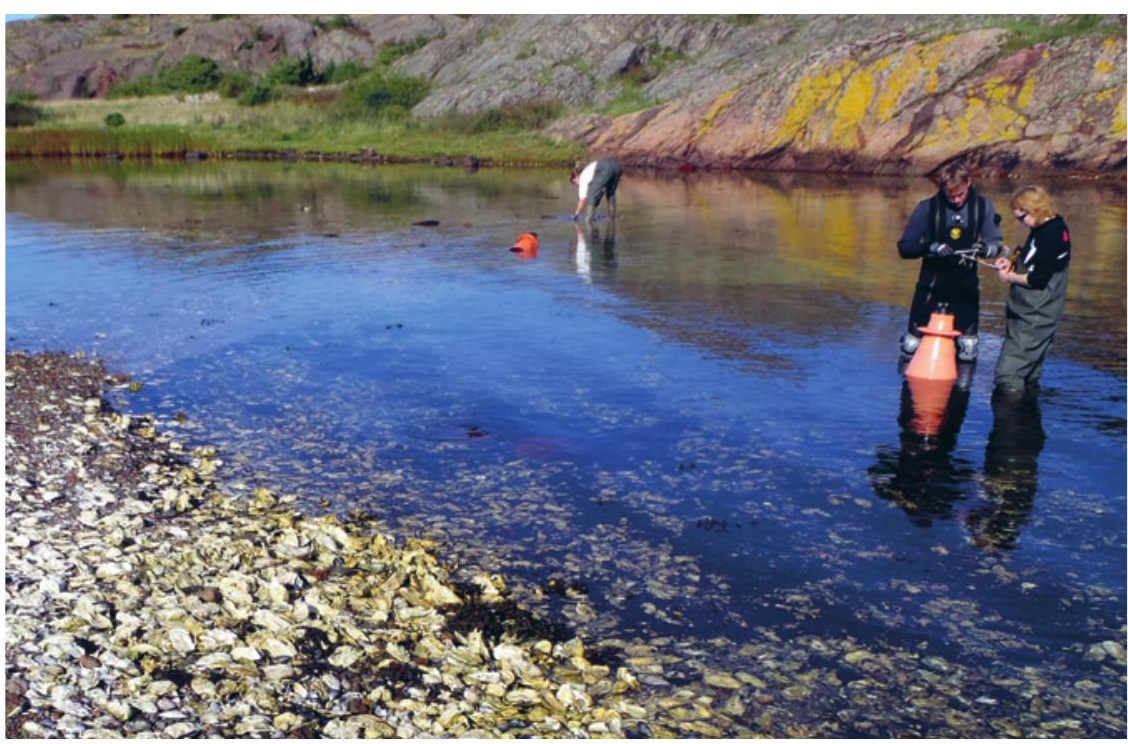




\section{Konklusioner og anbefalinger}

Bestræbelserne på at etablere en fælles nordisk model for kortlægning og monitorering af bestande af stillehavsøsters bør fortsættes.

Det er ikke muligt at udrydde de skandinaviske bestande af stillehavsøsters. Vi foreslår at forsøg, hvor østers fjernes fra udvalgte områder, bør forbindes til monitorering af bestandene og udføres i overensstemmelse med en generel procedure. På denne måde kan vi gribe håndteringer an på en videnskabelig måde, hvilket giver mulighed for at evaluere og udvikle denne aktivitet yderligere. Kortlægning og monitorering bør indbefatte blåmuslinger og europæisk østers for at opbygge datasæt for disse arter og identificere mulige interaktioner med stillehavsøsters.

De fjernede østers bør benyttes som menneskeføde eller industriel bearbejdning for at opnå en optimal og ansvarlig brug af ressourcen.

Etablering af kommercielle østersvirksomheder har stort potentiale. Fremtidige projekter kan inkludere akvakultur, høst til indtag af mennesker, industrielle produkter og turisme. Dog findes der adskillige udfordringer, der skal overvindes for at frigive denne ressources potentiale:
I Norge og Sverige har grundejerne rettighed til at høste ressourcer på lavt vand. Juridiske forhold i forbindelse med rettigheden til høst skal afklares.

- Fødevaresikkerhed er afgørende for forbrugernes tillid til produktet. Der er et behov for mere videnskabelig data og udvikling af metoder til etablering af et udgangspunkt for kvalitetskontrol af stillehavsøsters og forbrugersikkerhed. Værktøjer til risikovurdering bør udvikles inden for et nordisk samarbejde for at sikre optimal udnyttelse af kompetencer og eksisterende data.

- Industrien har behov for en model for opbevaring af kommercielt høstede østers, enten på afgrænsede bundkultursområder eller i faciliteter på land.

- Der bør udvikles nye virksomhedsmodeller der kombinerer naturforvaltning, høst og turisme. Dette kan inkludere samarbejder mellem myndigheder og private virksomheder, hvilket muliggør høstaktiviteter der kan bidrage til lokale målsætninger for naturforvaltning. 


\section{Udvalgt litteratur}

Laugen et al. 2015. The Pacific Oyster

(Crassostrea gigas) invasion in Scandina-

vian coastal waters in a changing climate:

impact on local ecosystem services. In Clode, J.C. (Ed.) Biological Invasions in Changing Ecosystems-Vectors, Ecological Impacts, Management and Predictions. De Gruyter Open, Berlin. s. 230-252.

Mortensen et al. 2017. Effects of a bio-invasion of the Pacific oyster, Crassostrea gigas (Thunberg, 1793) in five shallow water habitats in Scandinavia. Managing Biological Invasions 8: 543-552.

Mortensen et al. 2016. Summer mortalities and detection of ostreid herpesvirus microvariant in Pacific oyster Crassostrea gigas in Sweden and Norway. Diseases in Aquatic organisms. 117: 171-176.

Dolmer et al. 2014. The invasive Pacific oyster, Crassostrea gigas, in Scandinavian coastal waters: A risk assessment on the impact in different habitats and climate conditions. Fisken og Havet, 2: 1-67.

Strand et al. 2012. Impact of an icy winter on the Pacific oyster (Crassostrea gigas Thunberg, 1793) populations in Scandinavia. Aquatic Invasions, 7: 433-440. 


\section{Fakta om stillehavsøsters}

Latin: Crassostrea gigas

Familie: Ostreidae

Levetid: Mere end 20 år, kan blive mere end $25 \mathrm{~cm}$ lang, maksimal vægt over 1,5 $\mathrm{kg}$.

Levested: Lever fæstnet til hårdt substrat, almindeligvis sten eller muslingeskaller, fra den litorale zone og ned til et par meters dybde.
Gydeområde og -tidspunkt: Gyder om sommeren - afhængigt af høje vandtemperaturer. Befrugtning sker i vandet og larverne lever som plankton i adskillige uger før de fæstner sig permanent.

Spredning: Stort spredningspotentiale grundet et højt antal larver fra hver gydende hun og en lang planktonfase, hvor larver kan blive transporteret over lange distancer af havstrømme.

Føde: Bakterier, fytoplankton, andre mikroorganismer og detritus.

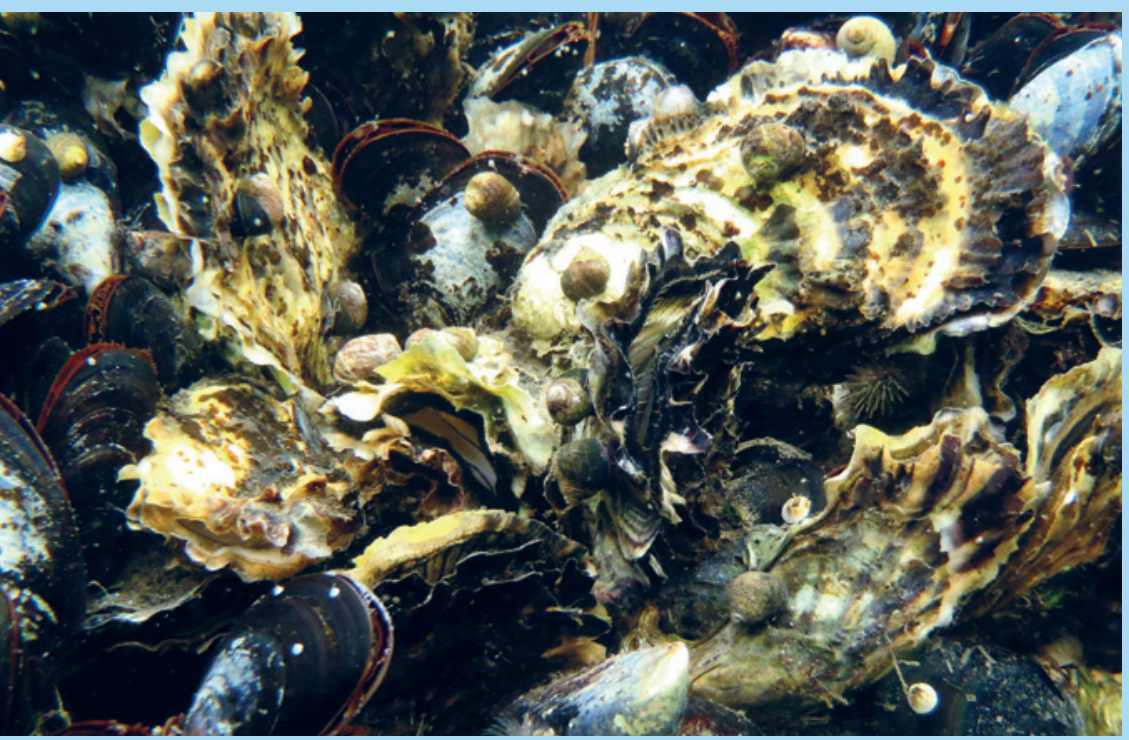

Østers på blåmuslingebanke

Foto: Åsa Strand $\leftarrow$ 


\section{Forskelle mellem stillehavsøsters og europæisk østers}

Europæisk østers, Ostrea edulis, er oprindeligt hjemmehørende i skandinaviske farvande. Den lever i den litorale zone og ned til et par meters dybde. Skalformen varierer. Skallerne er almindeligvis runde og flade, med en jævn brunlig grå farve, nogle gange med en snert af grøn. Overfladen har tynde krumninger og en struktur af flager.

Stillehavsøsters vokser typisk i den litorale zone, blotlagt under lavvande. Den har en grovere skaloverflade med få dybe krumninger og skarpe kanter. Skallerne er typisk lange med en skålfomet underskal og en relativt flad overskal. Skallens overfladen har ofte radiale brunlige eller violette striber.

Det kan være svært at bestemme arten på østersyngel. Nogle gange kan østers med en størrelse på få centimeter også være udfordrende. I de fleste tilfælde er det let at bestemme arten af østers, der er større end en tommelfingernegl, baseret på form, farve og skallens struktur.

Vores hjemmehørende europæisk østers (til venstre) er rund, flad og har en jævn, fint bølget skaloverflade. Stillehavsøstersen er oftest aflang og har dybere underskal og en grov, bølget skaloverflade, ofte med mørke striber. I de fleste tilfælde er det enkelt at skille artene fra hinanden.

Foto: Stein Mortensen $\rightarrow$

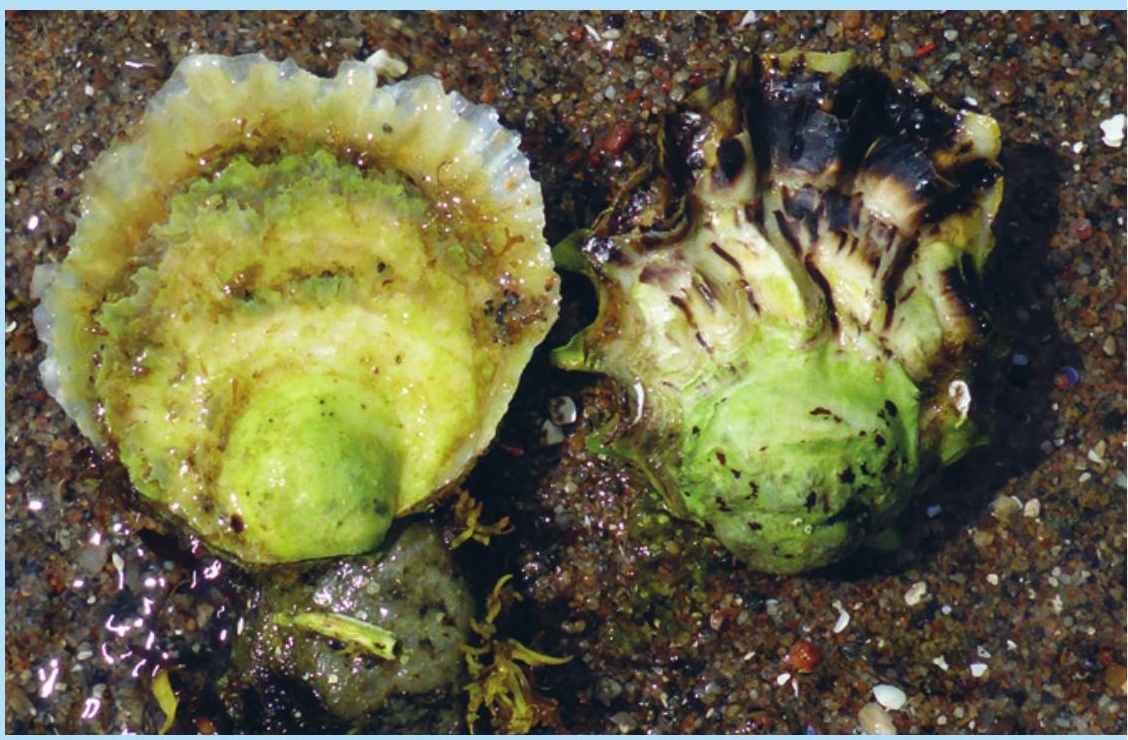




\section{Kontakt}

\section{Stein Mortensen, projektleder}

Institute of Marine Research, Bergen,

Norway

+4795755419 / stein.mortensen@hi.no

\section{Per Dolmer}

Orbicon, Viby J., Denmark

+45 21347781 / pdol@orbicon.dk

\section{Åsa Strand}

IVL Svenska Miljöinstitutet, Göteborg,

Sweden

+46 107886605 / asa.strand@ivl.se

\section{Lars-Johan Naustvoll}

Institute of Marine Research, Flødevigen, Norway

+4795246102 / larsjn@hi.no

\section{Ane Timenes Laugen}

University of Agder, Department of

Natural Sciences, Centre for Coastal

Research, Kristiansand, Norway

+4738141451/ ane.t.laugen@uia.no 


\section{Høst af stillehavsøsters}

Dette Policy Brief udgives af projektet "Harvesting Pacific oysters", et formandskabsprojekt finansieret af Nordisk

Ministerråd, blå bioøkonomi, i perioden 2017-2019. Det primære formål har været at afklare afgørende spørgsmål og videnskabelige problemstillinger relateret til høst af skandinaviske stillehavsøsters - forbundet til både bekæmpelsesstrategier og udnyttelse som en ny fødevareressource. 
Nordisk Ministerråd

Nordens Hus

Ved Stranden 18

1061 København $\mathrm{K}$

www.norden.org

Siden 2007 har stillehavsøsters etableret selvforsynende bestande i skandinaviske farvande. Arten anses som fremmed og invasiv, og er således uønsket. Kompakte bestande kan forårsage ændringer i bundforholdene. Den er dog også en af verdenens vigtigste akvakultur-arter, og der er en voksende interesse i, at bruge de skandinaviske bestande som en ny marin ressource. Der er behov for en bedre forståelse af, hvordan østersen påvirker økosystemet, samt bestands- og spredningsmodeller. For at sikre en ansvarlig brug af ressourcen, bør østers indsamlet fra strande og offentlige område i forbindelse med rydningskampagner benyttes som fødevare eller i industriel forarbejdning. Stillehavsøsters i Skandinavien åbner muligheder for nye, kommercielle aktiviteter, inklusiv turisme. For at frigøre det kommercielle potentiale er der behov for en afklaring af flere juridiske forhold såvel som etablering af en forvaltningspraksis for høst og markedsføring af disse østers. Fødevarekontrol bør også være på plads, for at garantere at kun sikre og sunde østers kommer på markedet. 